\title{
Metode Spiritual Penghayat Kapribaden Dalam Menjalin Hubungan Dengan Sang Pencipta
}

\author{
Satria Adhitama \\ Politeknik Keuangan Negara STAN \\ satria.bc@pknstan.ac.id
}

\begin{tabular}{l}
\hline Keywords: \\
\hline Belief, \\
Discrimination, \\
Kapribaden, \\
Kunci, Religion \\
\hline
\end{tabular}

\begin{abstract}
There are hundreds of beliefs in Indonesia, one of which is Kapribaden. The essence of Kapribaden's teachings is a spiritual practice by starting to know yourself as a human being and after that you can only know God. Before knowing God, Kapribaden followers must understand human nature first. This study aims to dig deeper into how Kapribaden believers establish a relationship with the Creator. This study uses a constructivist paradigm with interview data collection methods and literature study. There is a method or method known as Panca Gaib or Sarana Gaib to connect Kapribaden followers with God, namely Kunci, Asmo, Mijil, Singkir, and Paweling. By understanding this, it is hoped that the public can get a clear picture of the relationship between Kapribaden followers and God, so that acts of discrimination can be minimized.
\end{abstract}

Kata Kunci:

Diskriminasi, Kapribaden, Kebatinan, Kepercayaan, Kunci

\begin{abstract}
Abstrak
Terdapat ratusan aliran kepercayaan di Indonesia salah satunya adalah Kapribaden. Inti ajaran Kapribaden adalah sebuah laku spiritual dengan memulai mengenal diri sendiri sebagai manusia dan setelah itu baru bisa mengenal Tuhannya. Sebelum mengenal Tuhan, penghayat Kapribaden harus memahami hakikat manusia terlebih dahulu. Penelitian ini bertujuan untuk menggali lebih dalam bagaimana penghayat Kapribaden menjalin hubungan dengan Sang Pencipta. Penelitian ini menggunakan paradigma konstruktivis dengan metode pengumpulan data wawancara dan studi pustaka. Terdapat metode atau cara yang dikenal sebagai Panca Gaib atau Sarana Gaib untuk menghubungkan penghayat Kapribaden dengan Tuhan yaitu Kunci, Asmo, Mijil, Singkir, dan Paweling. Dengan memahami hal tersebut, diharapkan masyarakat dapat memperoleh gambaran yang jelas tentang hubungan antara penghayat Kapribaden dengan Tuhan, sehingga tindakan diskriminasi bisa diminmalisasi.
\end{abstract}




\section{Pendahuluan}

Esensi dari sebuah agama adalah mengatur bagaimana hubungan antara manusia dengan Tuhannya. Islam sebagai salah satu agama besar di Indonesia mengenal konsep tersebut dengan istilah habluminallah (Kumparan, 2021). Hal tersebut tercantum dalam kitab suci Al Quran surat An Nisa ayat 36 yang mengatakan "Sembahlah Allah dan janganlah kamu mempersekutukan-Nya dengan sesuatupun. dan berbuat baiklah kepada dua orang ibu-bapak, karib-kerabat, anak-anak yatim, orang-orang miskin, tetangga yang dekat dan tetangga yang jauh, dan teman sejawat, ibnu sabil dan hamba sahayamu. Sesungguhnya Allah tidak menyukai orang-orang yang sombong dan membanggabanggakan diri." Konsep ini diperkuat dengan surat Al Qasas ayat 77 yang mengatakan "Dan carilah (pahala) negeri akhirat dengan apa yang telah dianugerahkan Allah kepadamu, tetapi janganlah kamu lupakan bagianmu di dunia dan berbuatbaiklah (kepada orang lain) sebagaimana Allah telah berbuat baik kepadamu, dan janganlah kamu berbuat kerusakan di bumi. Sungguh, Allah tidak menyukai orang yang berbuat kerusakan.”

Begitu juga dalam Alkitab, agama Kristen baik Protestan maupun Katolik mengatur umat Nasrani untuk menjalin hubungan yang harmonis dengan Tuhan (Alkitab Sabda, 2021). Konsep ini dikenal sebagai Hukum Kasih atau Hukum yang Terutama yang mendasari seluruh ajaran Kristen. Hal tersebut tercantum salah satunya dalam Kitab Markus 12: 28 - 31 yang mengatakan "Lalu seorang ahli Taurat, yang mendengar Yesus dan orang-orang Saduki bersoal jawab dan tahu, bahwa Yesus memberi jawab yang tepat kepada orang-orang itu, datang kepada-Nya dan bertanya: "Hukum manakah yang paling utama?" Jawab Yesus: "Hukum yang terutama ialah: Dengarlah, hai orang Israel, Tuhan Allah kita, Tuhan itu esa. Kasihilah Tuhan, Allahmu, dengan segenap hatimu dan dengan segenap jiwamu dan dengan segenap akal budimu dan dengan segenap kekuatanmu. Dan hukum yang kedua ialah: Kasihilah sesamamu manusia seperti dirimu sendiri. Tidak ada hukum lain yang lebih utama dari pada kedua hukum ini."

Agama Hindu juga mengajarkan umatnya untuk menjalin hubungan yang harmonis dengan Tuhan atau Sang Hyang Widi Washa. Ajaran tersebut tertuang dalam konsep Tri Hita Karana yang berarti Tiga Penyebab Kebahagiaan (Aminah, 2003). Tri Hita Karana terdiri dari parahyangan, pawongan, dan palemahan. Parahyangan berarti mengajarkan manusia untuk memiliki hubungan yang harmonis dengan Tuhan, pawongan mengajarkan manusia untuk berhubungan harmonis dengan sesama umat manusia, dan palemahan mengajarkan manusia untuk menjaga alam semesta. 
Agama Buddha juga mengajarkan bagaimana seorang manusia untuk menggapai Tuhan seperti yang dituliskan Kalama (2013) dalam Sutta Pitaka, Udana VIII: 3 yaitu "Ketahuilah para Bhikkhu bahwa mempunyai sesuatu Yang Tidak Dilahirkan, Yang Tidak Menjelma, Yang Tidak Tercipta, Yang Mutlak. Duhai para Bhikkhu, apabila Tidak mempunyai Yang Tidak Dilahirkan, Yang Tidak Menjelma, Yang Tidak Diciptakan, Yang Mutlak, karenanya tidak akan mungkin kita bisa bebas sama sekali dari lahir, penjelmaan, pembentukan, pemunculan dari karena yang lalu. Tetapi para Bhikkhu, karena mempunyai Yang Tidak Dilahirkan, Yang Tidak Menjelma, Yang Tidak Tercipta, Yang Mutlak, karenanya mempunyai kemungkinan untuk bebas sama sekali dari lahir, penjelmaan, pembentukan, pemunculan dari karena yang lalu."

Begitu juga agama Khonghucu mengajarkan konsep hubungan antara manusia dengan Tuhan dan dengan sesama manusia. Menurut Nuwardani (2016), hubungan antara manusia dengan Tuhan atau yang dikenal oleh umat Khonghucu sebagai Thian, tercantum dalam Sabda Suci XVI dari Nabi Kongcu yang mengatakan "Seorang Kuncu-Susilawan memuliakan tiga hal. Memuliakan Firman Tuhan Yang Maha Esa, memuliakan orangorang besar, dan memuliakan sabda para nabi."

Berdasarkan penjelasan tersebut di atas, pada dasarnya setiap agama mengajarkan dua hal pokok yaitu bagaimana menjalin hubungan yang harmonis dengan Tuhan dan juga dengan sesama manusia. Selain itu semua agama juga mengajarkan kebaikan. Namun realitanya banyak agama khususnya agama lokal atau agama Nusantara sering kali dianggap sebagai agama sesat. Hal seperti yang diungkapkan oleh Zulkifli dkk (2019) bahwa tekanan dan diskriminasi terus terjadi kepada aliran kepercayaan. Pada zaman Orde Baru dan hingga saat ini aliran kepercayaan dianggap sebagai agama yang menyimpang bahkan bisa dikatakan sesat. Menurut Nadlir (2017) melalui kompas.com mengatakan bahwa sampai dengan tahun 2017, terdapat 187 kelompok aliran kepercayaan yang tersebar di seluruh Indonesia dan sudah terdaftar di pemerintah termasuk aliran kepercayaan Kapribaden. Stigma aliran sesat ini sering terjadi karena ketidaktahuan masyarakat (Adhitama, 2020), aliran kepercayaan sering kali dianggap sebagai penyembahan berhala atau setan bahkan dianggap sebagai animisme dan dinamisme. Bahkan zaman Orde Baru, para penghayat Kapribaden sering kali dianggap sebagai bagian dari Partai Komunis Indonesia atau PKI (Widhana, 2017). Ketidaktahuan ini harus segera diatasi dengan memberi penjelasan secara gamblang mengenai ajaran dari setiap aliran kepercayaan termasuk Kapribaden. 
Kapribaden adalah salah satu organisasi aliran kepercayaan yang sah dan terdaftar oleh pemerintah (Budiantoro, 2010). Kepribaden adalah sebuah laku spiritual yang diawali ketika Romo Herucokro Semono mendapat ilham (Raharjo, 1993). Penghayat Kapribaden tersebar di beberapa provinsi di Pulau Jawa khususnya DKI Jakarta, Daerah Istimewa Jogjakarta, Jawa Tengah, dan Jawa Timur. Tujuan penelitian ini adalah untuk menggali lebih dalam dan memberikan gambaran lebih jelas bagaimana para penghayat Kapribaden menjalin hubungan dengan Sang Pencipta. Dengan begitu, wawasan dan pengetahuan masyarakat bertambah dan sedikit demi sedikit stigma negatif terhadap aliran kepercayaan semakin berkurang.

\section{Metode}

Paradigma konstruktivis adalah paradigma yang digunakan dalam penelitian ini di mana paradigma ini menggambarkan cara pandang peneliti untuk menjelaskan kerangka sosial yang terbentuk dalam pola pikir seseorang maupun kelompok berdasarkan akal sehat tentang bagaimana subjek penelitian memberi makna pada suatu peristiwa atau kejadian dalam hidupnya (Poerwandari, 2007). Pendekatan yang digunakan adalah kualitatif dengan maksud untuk mengeksplorasi dan memahami makna yang oleh seseorang atau sekelompok orang dianggap berasal dari masalah sosial atau kemanusiaan. Pendekatan ini dipilih mengingat peneliti ingin melihat secara mendalam bagaimana metode hubungan antara penghayat Kapribaden dan Tuhan Yang Maha Esa. Penelitian ini bersifat deskriptif yang menyajikan gambaran atau penjelasan seteliti mungkin mengenai suatu fenomena/gejala berdasarkan data yang diperoleh. Teknik pengumpulan data dalam penelitian ini adalah teknik wawancara secara mendalam dan studi pustaka. Wawancara dilakukan kepada Sekretaris Jenderal Paguyuban Penghayat Kapribaden Ny. E. Retno Lastani. Studi pustaka dilakukan dengan mendapatkan data melalui bahan bacaan tentang ajaran Kapribaden. Proses analisis data dilakukan dengan proses hermeneutik dengan melakukan perbandingan antara data yang diperoleh dengan kerangka pemikiran atau acuan konsep dan digambarkan kembali sesuai data empiris.

\section{Hasil dan Pembahasan}

Kapribaden adalah sebuah laku spiritual dengan memulai mengenal diri sendiri sebagai manusia. Seorang manusia tidak akan mengenal Tuhannya sebelum manusia tersebut mengenal diri sendiri sebagai manusia. Seorang penghayat Kapribaden harus 
memahami terlebih dahulu esensi manusia dalam perspektif Kapribaden agar dapat menjalani laku spiritual ini.

\section{Organisasi Paguyuban Penghayat Kapribaden}

Seluruh aliran kepercayaan atau aliran kebatinan di Indonesia harus membentuk organisasi dan mendaftarkan diri ke pemerintah. Dengan begitu, secara hukum organisasi tersebut terdaftar dan berada di bawah pembinaan pemerintah khususnya Kementerian Pendidikan dan Kebudayaan (Kemendikbud) dan Kementerian Dalam Negeri (Kemendagri). Tujuan dari pendaftaran tersebut adalah mempermudah pengurusan izin apabila kelompok penghayat menyelenggarakan suatu kegiatan. Menurut laman resmi Paguyuban Penghayat Kapribaden (https://www.kapribaden.org/O_Organisasi.php) aliran kebatinan Kapribaden memiliki organisasi yang bernama Paguyuban Penghayat Kapribaden yang didirikan pada tanggal 30 Juli 1978 di Taman Mini Indonesia Indah Jakarta. Organisasi ini sudah terdaftar dan diakui secara sah oleh negara sebagai Organisasi Kemasyarakatan Tingkat Nasional di Bidang Agama/Kepercayaan terhadap Tuhan Yang Maha Esa berdasarkan Undang-Undang Nomor 8 tahun 1985 tentang Organisasi Kemasyarakatan. Selain itu Paguyuban Penghayat Kapribaden juga tercantum pada pengumuman pemerintah tentang organisasi-organisasi kemasyarakatan yang sah tingkat nasional dan Paguyuban Penghayat Kapribaden berada di nomor 324. Paguyuban ini didirikan sebagai sabdho Romo Herucokro Semono kepada putro-putro Romo Heru Cokro Semono (penghayat Kapribaden penerus ajaran Romo Herucokro Semono) dan secara khusus diperintahkan kepada Bapak Wahyono Rahardjo beserta Ibu Hartini Wahyono untuk membentuk sebuah paguyuban yang dinamakan Paguyuban Penghayat Kapribaden.

Berikut adalah usaha para penghayat Kapribaden dalam memenuhi peraturan pemerintah mengenai organisasi kemasyarakatan di mana Paguyuban Penghayat Kapribaden telah terdaftar di Departemen Pendidikan dan Kebudayaan Republik Indonesia dengan nomor 1.099/F.3/N.1.1/1980. Selain itu Paguyuban Penghayat Kapribaden juga terdaftar di Kejaksaan Agung Republik Indonesia dengan nomor 250 tahun 1986. Paguyuban Penghayat Kapribaden juga sudah memiliki Tanda Pemaparan Ajaran yang dikeluarkan oleh Departemen Pendidikan dan Kebudayaan nomor 31/F.6/F.5/1988 dan terakhir surat keterangan di Kementerian Dalam Negeri bahwa Paguyuban Penghayat Kapribaden adalah organisasi yang sah dan terdaftar nomor 29/D.III.3/III/2008. 
Selain memperoleh legalitas, tujuan dibentuknya Paguyuban Penghayat Kapribaden adalah menjadi wadah bagi para penghayat untuk melestarikan kemurnian laku Kapribaden dari Romo Herucokro Semono. Selain itu tujuan dibentuknya organisasi adalah sebagai wadah dari putro-putro Romo Heru Cokro Semono. Organisasi Paguyuban Penghayat Kapribaden juga merupakan pengayom dan pelindung bagi warga Paguyuban Penghayat Kapribaden dalam menjalankan laku Kapribaden. Organisasi ini juga sebagai sarana guyub rukun putro-putro Romo Heru Cokro Semono.

Pada dasarnya aliran kebatinan Kapribaden tidak mengenal organisasi yang resmi dan kaku seperti yang dianjurkan oleh pemerintah. Para penghayat Kapribaden tergabung dalam suatu wadah yang dikenal dengan kekadhangan. Kekadhangan ini lebih menekankan hubungan antar manusia sesama penghayat Kapribaden di mana hubungan yang terjadi adalah hubungan spiritual melebihi saudara kandung. Semua penghayat Kapribaden memiliki kedudukan yang sama dalam kekadhangan, tidak seperti guru dan murid, senior dan yunior, atan dan bawahan, namun lebih kepada hubungan persaudaraan yang sama-sama silih asah, silih asih, silih asuh, gosok ginosok berdasarkan pengalaman masing-masing (Syafi'udin, 1996).

\section{Romo Herucokro Semono}

Romo Herucokro Semono adalah orang yang pertama mendapat ilham dan membentuk laku Kapribaden. Menurut laman resmi Paguyuban Penghayat Kapribaden (https://www.kapribaden.org/Romo\%20Herucokro\%20Semono.php) Romo Herucokro Semono terlahir dengan nama Semono pada tahun 1900 dan wafat pada tahun 1981. Semono sejak kecil diasuh oleh tokoh spiritual bernama Ki Kasandhikromo atau dikenal dengan nama KI Kasan Kesambi di Desa Kalinongko Gunung Damar Kecamatan Loano, Purworejo, Jawa Tengah.

Sejak berumur 14 tahun, Semono remaja sudah melakukan semedi atau bertapa di tepi Laut Selatan daerah Cilacap selama tiga tahun . Hasil dari semedi atau pertapaan tersebut adalah Romo Semono mendapat ilham atau wangsit untuk melakukan laku hingga tahun kembar 55 yang berarti beliau harus menjalani laku hingga tahun 1955. Pada tanggal 13 November 1955 malam hari, Romo Herucokro Semono mendapat wangsit atau wahyu. Rumah beliau di Jalan Perak Barat Nomor 93 Surabaya tampak terbakar namun bukan api melainkan cahaya, bahkan banyak orang melihat kereto kencono yang turun dari langit masuk ke kediaman Romo Herucokro Semono. Peristiwa tersebut terjadi karena Romo Herucokro Semono sedang mijil. Beliau mengatakan "Ingsun mijil, arso 
nyungsang bawono balik, arso nggelar jagat anyar" yang berarti "Ingsun (bukan aku) mijil hendak memutarbalikkan jagad (buana alit, mikrokosmos, atau pribadi manusia) dan hendak menggelarkan dunia baru (mikrokosmos baru atau manusia yang baru)." Arti dari perkataan tersebut adalah apabila selama ini manusia selalu meperbudak Hidup, maka semenjak saat itu manusia menjadi abdi Sang Hidup.

Sebelum melakukan mijil tersebut, Romo Herucokro Semono telah menerima wangsit atau wahyu yaitu Panca Gaib yang terdiri dari kunci, asmo, mijil, singkir, dan paweling. Beliau juga mengemban tugas suci untuk memberi pencerahan (pepandangan) kepada sesama manusia untuk mengenalkan manusia kepada Sang Hidup di dalam raga setiap manusia agar manusia tersebut dapat menerima petunjuk-Nya dan juga tuntunan hidup agar dapat mengikuti arahan menuju kepada sumber Hidup yaitu Gusti Ingkang Moho Suci, Tuhan Yang Maha Esa. Semasa hidupnya Romo Herucokro Semono menerima banyak tamu tak kenal waktu. Semua dilayani tanpa memandang status, latar belakang, agama, dan identitas lainnya, semua diperlakukan sama. Orang berdatangan dari berbagai macam daerah termasuk dari luar negeri, setiap orang dapat memahami petuah atau walang wuruk Romo Herucokro Semono walaupun mereka tidak bisa berbahasa Indonesia atau berbahasa Jawa. Setiap orang mendengar dengan bahasanya masing-masing, setiap orang dengan latar belakang bahasa yang berbeda mampu memahami apa yang Romo bicarakan. Peninggalan Romo Herucokro Semono yang tak ternilai adalah sarana-sarana gaib, bagi orang-orang yang ingin mencari hidup bahagia atau tentrem, sehingga orang tersebut dapat melaksanakan dan memperoleh "Kasampurnan Jati”. Peninggalan Romo ini yang hingga saat ini terus dipelihara dan dilaksanakan oleh putro-putro.

\section{Inti Ajaran Kapribaden}

Kapribaden adalah sebuah laku spiritual yang dimulai dengan mengenal diri sendiri sebagai manusia dan setelah itu seseorang baru bisa mengenal Sang Pencipta. Sebelum mengenal Sang Pencipta, penghayat Kapribaden harus memahami hakikat manusia menurut Kapribaden. Menurut Raharjo (1993), pada dasarnya manusia merupakan badan (raga) dan Hidup (nyawa, roh, atau jiwa). Badan atau raga manusia terbentuk dari beberapa unsur yaitu tanah (unsur-unsur kimia organik dan anorganik), air (sekitar 70\% tubuh manusia adalah air), hawa atau udara (gas), api (energi atau kalori). Unsur-unsur tersebut berproses secara biologis dan kimiawi, pada ayah terbentuk sel sperma (air mani) dan pada ibu terbentuk sel telur. Pertemuan sel sperma dan sel telur 
membentuk raga manusia. Setelah raga manusia terbentuk, Sang Hidup akan memasuki raga tersebut. Setelah itu raga tersebut berkembang menjadi embrio atau janin, menjadi bayi, yang pada akhirnya dilahirkan sebagai manusia ke dunia.

Menurut Fauziyah (2014), raga manusia terdiri dari tujuh lapis, yaitu rambut, kulit, daging atau otot, otot atau saraf, tulang, sumsum, dan darah (semua cairan tubuh). Hidup berasal dari Tuhan Yang Maha Esa disebut juga Roh Suci karena Hidup berasal dari Maha Suci. Setelah Hidup menyatu dengan raga disebut sebagai Hidup (Urip). Awal kehidupan manusia, seorang bayi sudah mendapatkan pengajaran dari Guru Sejati yaitu Hidup. Tangis bayi dan gerak bayi semua sama tak dapat dibedakan apakah bayi tersebut berasal dari suku atau ras apapun, yang membedakannya adalah selama perkembangan, bayi tersebut mendapat masukan dari lingkungan yang berbeda. Namun pada dasarnya manusia dilahirkan sama. Namun perbedaan manusia adalah raganya, raga terbentuk dari sel ayah dan sel ibu yang berbeda berarti tanah, air, hawa, dan api yang berbeda juga. Jadi, jika manusia menggunakan ukuran atau standar Hidup, pasti akan sama dalam menilai segala hal karena Hidup berasal dari Sang Maha Tunggal.

Raharjo (1193) menjelaskan bahwa raga adalah hal yang bersifat material dan bersifat tidak abadi. Suatu saat akan mati, hancur, dan kembali menjadi unsur dasar manusia yaitu tanah, air, hawa, dan api. Sedangkan Hidup adalah sesuatu yang tidak bersifat material, bersifat abadi, berasal dari Yang Maha Abadi. Hidup berasal dari Tuhan, sehingga ketika Hidup berpisah dengan raga, Hidup akan segera kembali ke Tuhan. Dalam pemahaman Kapribaden, otak beserta fungsinya (psikis atau jiwa) juga merupakan bagian dari raga, karena otak dan jiwa merupakan kerja organ tubuh yang bersifat material. Begitu juga dengan akal pikiran (logika dan rasio) dan emosi adalah bagian dari raga. Sedangkan Hidup adalah kuasanya Gerak, terletak di feeling atau rasa. Maka, jika manusia ditinggal oleh Hidup, maka tidak memiliki kuasa untuk bergerak dan juga kehilangan rasa atau feeling. "Urip iku kuwasane obah, lenggahe ono ing Roso Jati” yang berarti Hidup itu kekuatan untuk bergeral, berada di Roso Jati.

Setiap waktu manusia berjalan bersama-sama di jalannya masing-masing selangkah demi selangkah menuju kematian. Ada manusia dengan langkah yang cepat, ada pula dengan langkah yang lambat. Hal tersebut merupakan perjalanan raga manusia. Sering kali manusia mengabaikan perjalanan Hidup. Hidup sering kali dipaksa untuk mengikuti perintah raga yang dapat mengakibatkan salah arah. Padahal, apabila tidak terdapat Hidup, raga (manusia) tidak dapat berbuat apa-apa. Hidup menentukan arah dan 
langkah manusia, sedangkan raga hanya menyesuaikan arahan dari Hidup. Hidup tidak akan pernah salah karena berasal dari Tuhan Yang Maha Esa dan Hidup selalu menuju kembali ke asalnya, yaitu Tuhan Yang Maha Esa. Sering kali Hidup dipaksakan untuk mengikuti kehendak atau kemauan raga, hal ini menyebabkan Hidup tidak dapat kembali menyatu (manunggal) kepada Sang Pencipta (Fauziyah, 2014). Manusia yang menjalani kehidupan, namun sering kali tidak sesuai dengan apa yang dikehendaki Tuhan atas dirinya, sehingga sering kali mengorbankan banyak hal seperti kebahagiaan keluarga, diri sendiri, dan masyarakat yang akhirnya membuat stres. Perlu diingat bahwa raga memiliki keterbatasan. Stres tersebut dapat menimbulkan berbagai macam penyakit baik fisik maupun psikologis. Apabila seseorang ingin selalu merasakan kebahagiaan sejati, orang tersebut harus mengikuti kehendak Hidup, karena Hidup mengetahui apa yang terbaik untuk seseorang, menurut Sang Maha Hidup, yaitu Tuhan Yang Maha Esa. Dengan begitu apabila manusia ingin mengikuti Hidup dan bertekad menjadi manusia baru, manusia akan dilahirkan kembali. Dengan menjalani laku seperti itu manusia tersebut menjadi Insan Spiritual di mana Hidup berbaju daging, tulang, dan saraf, dan tidak lagi menjadi Insan Material di mana daging, tulang, dan saraf yang dihidupi (Raharjo, 1993).

Inti dari ajaran Kapribaden adalah Hidup. Hidup itu adalah sesuatu yang gaib, eksistensinya tidak dapat dikenali dengan pancaindra. Hidup adalah kuasanya Gerak, terletak atau lungguhe berada di Rasa. Hidup tidak bisa disentuh, dibaui, dilihat, atau dirasa dengan lidah namun Hidup hanya bisa dirasakan dengan perasaan atau feeling. Menurut Budiarta (2020), penghayatan Kapribaden adalah penghayatan yang menuju sang pribadi atau menuju ke dalam diri dan memiliki sifat gulung yang berarti menuju ke rasa sejati. Perjalanan menuju titik akhir "lungguhing laku, ya pepuntoning laku" yaitu "daerah tan keno kinoyo ngopo" yaitu rasa semata-mata.

Seseorang yang ditinggalkan oleh Hidup pasti akan mati. Jika manusia mati, semua atribut yang pada diri orang tersebut seperti kekayaan, kepandaian, pengalaman, popularitas, kehebatan, jabatan, kehormatan, status sosial, bahkan orang-orang yang kita cintai tidak akan berguna atau berarti. Semua hal tersebut ada pada diri manusia karena ada Hidup atau dikenal dengan istilah isih kalenggahan Urip. Mengingat pentingnya Hidup dalam ajaran Kapribaden diharapkan putro-putro atau penghayat Kapribaden dapat membebaskan Hidup dan mulai menjadikan diri sebagai abdi dari Sang Hidup. Seluruh lapis raga manusia hendaknya tunduk dan menjadi abdi dari Sang Hidup, agar 
setiap waktu, raga diselamatkan dari hal-hal yang merugikan dan perbuatan yang nantinya bisa membuat dirinya tidak bahagia dan tidak dapat segera kembali kepada asal manusia.

\section{Metode Spiritual Mendekatkan Diri kepada Tuhan Yang Maha Esa}

Setiap agama atau kepercayaan memiliki tata cara atau metode spiritual masingmasing dalam berhubungan dengan Sang Pencipta. Secara umum metode tersebut dikenal dengan sembahyang atau ibadah. Namun setiap entitas agama atau kepercayaan memiliki penyebutan dan pelaksanaan yang berbeda-beda. Berdasarkan hasil wawancara dan beberapa kepustakaan, terdapat beberapa cara mendekatkan diri kepada Tuhan Yang Maha Esa menurut aliran kepercayaan Kapribaden yang dikenal dengan nama Panca Gaib atau Sarana Gaib.

\section{a. Kunci atau Ngunci}

Sarana Gaib yang pertama untuk mendekatkan diri kepada Sang Pencipta dalam lingkup penghayat Kapribaden dikenal dengan istilah kunci atau ngunci. Ngunci adalah bagaimana seseorang merasakan Hidup atau Tuhan Yang Maha Esa. Jadi ketika seseorang sudah me-ngunci, orang tersebut merasakan bahwa ada yang menghidupi. Jadi orang tersebut bisa bergerak, bisa merasakan atau melakukan sesuatu karena ada yang menghidupi. Jika orang tersebut mati, maka orang tersebut tidak dapat merasakan dunia dan seisinya. Ngunci merupakan kegiatan satu arah, dari Sang Hidup kepada raga. Dalam raga manusia terdapat Hidup yang menghidupi walaupun sering kali orang tersebut tidak merasakan disebabkan orang tersebut sedang menanggung banyak pikiran atau ego manusia yang masih tinggi. Akan tetapi Hidup akan selalu menuntun manusia walaupun orang tersebut tidak merasakan dan mengabaikan Hidup.

Kunci atau ngunci berarti seseorang tidak hanya percaya bahwa dalam diri terdapat Hidup, tetapi orang tersebut harus membuktikan dan merasakan sendiri bahwa Hidup itu benar-benar ada (Fauziyah, 2014). Apabila seseorang dengan sungguh-sungguh mempraktikan dan menghayati kunci, orang tersebut akan diberi bukti tidak hanya tentang eksistensi Hidup, akan tetapi tentang cara bekerja dan kuasa Hidup atas kehidupan dan penghidupan manusia sehari-hari. Langkah pertama melakukan kunci adalah merenungkan dan mempertimbangkan keinginan untuk hidup bahagia sejati atau tentram agar mampu mencapai Kasampurnaan Jati. Seseorang harus meyakini bahwa segala sesuatu sudah ditentukan dan kehendak Tuhan Yang Maha Kuasa.

Menurut Raharjo (1993), kunci memberikan bukti kepada diri masing masing bahwa Hidup itu memang ada dalam diri manusia. Dengan menggunakan Kunci, 
penghayat Kapribaden tidak hanya percaya bahwa terdapat Hidup dalam diri, tetapi membuktikan dan merasakan sendiri. Kata-kata dalam Kunci meruapakan bukan hasil pemikiran Romo Herucokro Semono dan tidak boleh ada yang diubah sedikitpun. Apabila kata-kata Kunci berubah satu kata saja, maka tidak akan berguna, dan bukan lagi Kunci. Kata-kata tersebut sama seperti ketika Romo Herucokro Semono menerima wangsit atau wahyu. Namun Romo Herucokro Semono menekan bahwa "Kunci iku dhudhu unine, dhudu unen-unene, nanging kang mahanani uni" yang berarti "Kunci itu bukan bunyinya, bukan kata-katanya, tetapi yang menyebabkan adanya bunyi." Bahkan Romo Herucokro Semono pernah menyatakan "Upomo kunci iku kudhu kaparingake marang wedus, mbokmenowo unine embek" yang berarti "Seandainya kunci itu harus diberikan kepada kambing, barangkali bunyinya embek." Kata-kata kunci adalah sebagai berikut "Gusti ingkang Moho Suci, Kulo nyuwun pangapuro dumateng Gusti ingkang Moho Suci; Sirolah, Dhatolah, Sipatolah; Kulo sejatine satriyo/wanito, nyuwun wicaksono, nyuwun panguwoso, kangge tumindhake satriyo/wanito sejati; Kulo nyuwun, kangge anyirnakake tumindhak ingkang luput." Untuk pria menggunakan kata satriyo, sedangkan untuk wanita menggunakan kata wanito. Sampai dengan saat ini, semua yang menghayati Laku Kasampurnan, apapun latar belakang suku, bangsa, dan bahasanya, dalam mengamalkan kunci harus tepat seperti yang diberikan oleh Romo Herucokro Semono. Kata-kata kunci tidak boleh diganti dengan bahasa lainnya.

Kunci diamalkan setiap saat sepanjang hari bahkan ketika seseorang tidak melakukan kegiatan apa-apa disarankan untuk melakukan kunci. Tujuan mengamalkan kunci agar seseorang senantiasa dilindungi oleh Hidup dan dihindarkan dari perbuatan salah termasuk perbuatan salah terhadap diri sendiri. Kunci juga melindungi para penghayat Kapribaden dari berbagai macam musibah, kecelakaan, malapetaka, dan marabahaya serta kejadian yang tidak mengenakan. Mengamalkan kunci tidak dalam waktu yang lama. Bisa jadi orang-orang yang masih awal menjalankan kunci terasa lama, akan tetapi apabila sudah terbiasa maka kunci dapat dilaksanakan dalam waktu beberapa detik. Kunci juga bisa digunakan untuk mencari solusi atau petunjuk, bisa jadi dengan melakukan kunci, seseorang mempersiapkan diri untuk menerima petunjuk. Dengan kunci, para penghayat Kapribaden selalu diingatkan bahwa manusia bukan siapa-siapa, seseorang bisa seperti ini karena adanya Hidup yang menghidupi.

Setelah kunci dilaksanakan, tujuh lapis raga manusia menyembah kepada Hidup. Dengan kunci, seorang penghayat berjanji untuk menjadi abdinya Hidup. Abdi dan 
sembah penghayat kepada Hidup, akan diteruskan kepada Sang Maha Hidup yang menghidupi alam semesta seisinya, Tuhan Yang Maha Esa (Fauziyah, 2014). Jadi, Kunci merupakan sebuah tanda dimulainya suatu penghayatan, yang sekaligus pengalaman suatu laku, yaitu yang disebut Laku Kasampurnan Manunggal Kinantenan Sarwo Mijil, atau dikenal dengan nama penghayatan Kapribaden. Pengamalan laku ini adalah selalu mengingat kepada Hidup dan selalu meminta petunjuk Hidup sebelum melakukan apapun dan mengikuti segala petunjuk Hidup, sekalipun bertentangan dengan keinginan dan kehendak diri. Karena Guru Sejatinya Hidup itu adalah manusia sendiri, maka Guru Sejati itu yang paling mengetahui atas diri manusia, dan Guru Sejati itu yang mengetahui apa sebenarnya kehendak Tuhan atas diri manusia, dan bagaimana seharusnya melaksanakan semua itu. Penghayatan Kapribaden tidak menyuruh orang atau para penghayatnya untuk meninggalkan hal-hal yang bersifat material atau duniawi. Hidup dijalani secara wajar, kesenangan duniawi boleh dirasakan dan dinikmati asalkan sesuai tuntunan Hidup agar tidak menimbulkan kesengsaraan atau kesedihan.

\section{b. Asmo}

Sarana Gaib yang kedua adalah asmo atau dalam bahasa Indonesia berarti nama. Pada waktu seseorang dilahirkan ke dunia, orang tua memberi nama (asmo) untuk raga bayi tersebut. Padahal, bayi yang baru saja dilahirkan memiliki raga serta Hidup di dalamnya. Sehingga, sering kali yang dikembangkan hanya raga. Agar seseorang dapat berhubungan atau berkomunikasi dengan Hidup, maka Hidup harus diberi asmo terlebih dahulu. Asmo hanya diberikan kepada orang-orang yang dengan sungguh-sungguh sudah membuktikan adanya Hidup melalui kunci dan sudah meyakini akan kuasa Hidup. Selain itu orang-orang tersebut harus memiliki keteguhan hati untuk mengikuti segala kehendak (karsanya) Hidup. Apabila Hidup sudah mendapat asmo berarti orang tersebut sudah sepenuhnya menjadi Penghayat Laku Kasampurnan Manunggal Kinantenan Sarwo Mijil atau Penghayat Kapribaden. Jika Hidup diingkari, suatu saat akan ditagih oleh Hidup itu sendiri. Dengan memiliki asmo, maka penghayat Kapribaden sudah memiliki penuntun yaitu Hidup-nya sendiri. Asmo diberikan oleh kadhang atau penghayat Kapribaden yang memang sudah diizinkan untuk memberikan asmo.

Terdapat dua jenis asmo untuk pria dan wanita. Setiap jenis memiliki dua asmo sehinga empat asmo. Untuk penghayat Kapribaden berjenis kelamin perempuan diberikan Asmo Kandi Warni atau Kandi Rupi. Sedangkan untuk pria, diberikan Asmo Konto Warno atau Konto Rupo. Pada dasarnya asmo-asmo tersebut bermakna sama yaitu Roh Suci. 
Asmo diberikan oleh penghayat Kapribaden yang hampir seluruh hidupnya mengikuti petunjuk Tuhan atau sesepuh yang kehidupan keluarganya itu baik. Dengan mendapat asmo berarti raga sudah menyatu dengan Roh Suci dan dapat mengikuti petunjuk Tuhan. Menurut Fauziyah (2014), fungsi dari asmo adalah sebagai sarana atau media untuk melakukan kunci, singkir, dan paweling.

\section{c. Mijil}

Sarana Gaib untuk mendekatkan diri kepada Tuhan yang ketiga adalah mijil. Mijil (Raharjo, 1993) berarti berkomunikasi dua arah dengan Hidup. Apabila seorang penghayat Kapribaden akan melakukan sesuatu, mijil ini seperti meminta izin supaya dilindungi atau diberi kemudahan karena tugas manusia hidup adalah mengikuti kehendak Hidup. Dengan mijil, seorang penghayat Kapribaden berkomunikasi dengan Hidup apakah yang dilakukan memang kehendak Tuhan atau keinginan raga atau nafsu saja. Dengan mijil, setiap aktivitas para penghayat Kapribaden, diharapkan mendapat perlindungan. Mijil dapat dilakukan setiap saat dalam aktivitas apapun. Menurut Fauziyah (2014), agar seseorang dapat menyatu dengan Hidup, selain dengan cara mijil, orang tersebut harus mampu membersihkan, menyucikan diri, menghilangkan ego, angkara murka seperti nafsu, serta menghindari mo limo. Mo limo tersebut adalah menghindari mo pertama: Minum, menghindari minuman yang memabukkan, mo kedua: Madat, menghindari narkoba, mo ketiga: Main, menghindari berjudi, mo keempat: Madon, menhindari berzina atau berselingkuh, dan mo kelima: Maling, menghindari mencuri.

Terdapat dua jenis kata dalam mijil (Raharjo, 1993). Yang pertama digunakan hanya dalam aktivitas yang bersifat spiritual atau gulung yaitu "(asmo), jeneng siro mijilo, panjenengan Ingsun kagungan karso, arso . . . . . . . . Misalnya ketika seorang penghayat Kapribaden diminta untuk mengobati seseorang, maka kata mijil yang digunakan adalah yang pertama. Yang mengusahakan pengobatan bukanlah orang tersebut melainkan Ingsun atau Hidup-nya. Yang kedua digunakan sebelum berbuat sesuatu apa saja atau gelar yaitu “(asmo), jeneng siro mijilo, panjenengan Ingsun kagungan karso, raganiro arso . . . . . . . . Baik pada kata-kata pertama atau kedua, bagian titik-titik setelah kata arso diisi dengan kegiatan apa yang ingin dilakukan dan menggunakan bahasa masing-masing. Mijil dilakukan kapan saja dan setiap akan melakukan apa saja "Arep tumindak opo wae, mijil". Setelah melakukan mijil, Hidup akan memberi petunjuk untuk melakukan suatu kegiatan atau tidak, apabila tidak mengikuti 
apa yang dipesankan oleh Hidup, kemungkinan akan terjadi hal yang kurang mengenakkan.

Hidup itu selalu benar dan petunjuk Hidup itu selalu baik dan benar. Akhirnya, apapun yang akan dikatakan orang, bahkan apapun akan dikatakan oleh logika dan rasio, penghayat Kapribaden akan lebih percaya terhadap apa yang dikatakan oleh Hidup. Hidup tidak akan berbuat jelek, tidak akan berbuat salah. Yang berbuat jelek dan salah adalah manusianya. Oleh karena itu sebelum melakukan sesuatu, para penghayat Kapribaden melakukan mijil terlebih dahulu.

\section{d. Singkir}

Singkir (Raharjo, 1993) adalah sarana Gaib yang keempat untuk berhubungan dengan Tuhan Yang Maha Esa. Tujuan mengamalkan singkir adalah untuk meminimalkan pengaruh "aku" dengan segala sifatnya, termasuk angkara murka dalam diri sendiri. Kata-kata yang digunakan dalam singkir adalah "Gusti Ingkang Moho Suci, kulo nyuwun pangapuro dumateng Gusti Ingkang Moho Suci; Sirolah, Dhatolah, Sipatolah; Kulo sejatine satriyo/wanito; Hananiro - hananingsun; Wujudiro wujudingsun; Siro sirno mati dhening satriyo / wanito sejati; Ketiban idhuku putih, sirno layu dhening (asmo)" Dengan berlatih melakukan singkir, "aku" semakin lama akan semakin menipis. Hal ini akan memudahkan para penghayat Kapribaden untuk mengamalkan laku, karena "aku” yang biasanya menjadi penentang, melawan atau menentang kehendak Hidup.

Menurut Raharjo (1993) “aku” adalah hambatan atau rintangan untuk melakukan laku Kapribaden karena biasanya yang menjadi penghambat atau perintang dalam mengamlkan laku adalah diri sendiri maka dikatakan sebagai "aku". "Aku" berisikan kesombongan (arrogancy), egoisme dan egosentrisme (mementingkan diri sendiri dan memandang segala sesuatu hanya dari sudut pandangnya sendiri), nafsu (lust), angkara (kesrakahan), kemalasan, dan ketidakacuhan (ignorancy). Sifat-sifat "aku" itu selalu bertentangan dengan sifat-sifat Hidup (Ingsun). Maka, agar seseorang bisa mengamalkan laku Kapribaden, orang tersebut harus bisa menyingkirkan "aku" dalam diri masingmasing dengan melakukan singkir.

"Aku" merupakan sifat yang sangat kuat menempel pada manusia karena selain bawaan lahir (gawan bayen), "aku" semakin berkembang dan semakin kuat seiring dengan pertumbuhan manusia. Mengalahkan "aku” tidak cukup dengan tekad akan tetapi seseorang harus menjalani laku dan harus dibantu dengan cara atau metode Sarana Gaib. 
Laku membersihkan raga (laku pangumbahing rogo) pada dasarnya merupakan upaya atau usaha untuk mengalahkan "aku". Laku tersebut diamalkan dengan sabar, narimo, ngalah, tresno welas lan asih marang opo lan sopo wae, dan ikhlas.

e. Paweling

Paweling (Raharjo, 1993) adalah Sarana Gaib yang kelima untuk menghubungkan Hidup dalam diri seseorang dengan Hidup yang meliputi (ngalimpudhi) alam semesta seisinya, yaitu Tuhan Yang Maha Esa. Keadaan seperti ini disebut Manunggal atau bisa juga disebut Manunggalnya Kawulo Gusti, atau manunggalnya Putro dengan Romo, atau Manunggalnya Hidup dengan Hidup yang menghidupi. (Putro adalah Hidup yang ada dalam diri kita, sedang Romo adalah Hidup yang meliputi, menggerakkan dan menguasai alam semesta seisinya). Menurut Endraswara (2015), Manunggaling Kawulo Gusti adalah sebuah pengalaman penyatuan atau peleburan diri antara seorang manusia dengan Tuhan Yang Mahaagung. Dengan kata lain Paweling adalah bersatunya mikrokosmos dan makrokosmos. Paweling yang dilakukan dengan benar akan mengakibatkan keadaan Manunggal / Menyatu dengan alam. Paweling yang benar dapat menghilangkan tempat, jarak, dan waktu. Seseorang dapat berada di lebih dari satu tempat dan pada waktu yang bersamaan. Kata-kata yang dilantunkan dalam paweling adalah "Siji-siji, loro-loro, telu-telonono; Siji sekti, loro dadi, telu pandito; Siji wahayu, loro gratrahino, telu rejeki."

\section{Kesimpulan}

Berdasarkan penjelasan tersebut di atas, dapat disimpulkan bahwa metode spiritual yang digunakan penghayat Kapribaden dalam menjalin hubungan dengan Sang Pencipta disebut Panca Gaib atau Sarana Gaib yaitu Kunci, Asmo, Mijil, Singkir, dan Paweling.

1. Kunci merupakan kondisi bagaimana seseorang merasakan Hidup. Jadi ketika seseorang sudah me-ngunci, orang tersebut merasakan bahwa ada yang menghidupi. Ngunci merupakan kegiatan satu arah, dari Sang Hidup kepada raga. Hidup akan selalu menuntun manusia walaupun orang tersebut tidak merasakan dan mengabaikan Hidup.

2. Asmo adalah nama untuk Hidup atau Roh Suci seseorang. Agar seseorang dapat berhubungan, berkomunikasi dengan Hidup, maka Hidup harus diberi asmo terlebih dahulu. 
3. Mijil berarti berkomunikasi dua arah dengan Hidup. Apabila seorang penghayat Kapribaden akan melakukan sesuatu, mijil ini seperti meminta izin supaya dilindungi atau diberi kemudahan karena tugas manusia hidup adalah mengikuti kehendak Hidup.

4. Singkir adalah untuk menipiskan "aku" dengan segala sifatnya, termasuk angkara murka dalam diri sendiri. "Aku" adalah hambatan atau rintangan untuk melakukan laku Kapribaden karena biasanya yang menjadi penghambat atau perintang dalam mengamalkan laku adalah diri sendiri maka dikatakan sebagai "aku”.

5. Paweling adalah cara atau metode untuk menghubungkan Hidup dalam diri seseorang dengan Hidup yang meliputi (ngalimpudhi) alam semesta seisinya, yaitu Tuhan Yang Maha Esa atau dikenal dengan Manunggaling Kawulo Gusti.

\section{Daftar Pustaka}

Adhitama, Satria. (2020). Konsep tri hita karana dalam ajaran kepercayaan budi daya. Dharmasmrti: Jurnal Ilmu Agama dan Kebudayaan, 20 (2), 29 - 45. https://doi.org/10.32795/ds.v20i2.1020

Aminah, Wiwin Siti, Haryandi, \& Alfrad Benedictus. (2003). Sejarah, teologi, dan etika agama-agama. Yogyakarta: Interfidei.

Alkitab Sabda. https://alkitab.sabda.org/passage.php?passage=mar\%2012:28-31

(Diakses pada tanggal 5 Agustus 2021)

Aryandini, Woro. (2011). Budaya nusantara I. Tangerang Selatan: Sekolah Tinggi Akuntansi Negara.

Aryandini, Woro. (2011). Budaya nusantara II. Tangerang Selatan: Sekolah Tinggi Akuntansi Negara.

Aryono. (2018). Pergulatan aliran kepercayaan dalam panggung politik indonesia, 1950an-2010an: romo semono sastrodihardjo dan aliran kapribaden. Jurnal Sejarah Citra Lekha, 3 (1), 58 - 68.

Balairungpress. (2017). Lepasmya aliran kepercayaan dari belenggu diskriminasi. $\begin{array}{lllll}\text { Diakses } & \text { pada } & \text { tanggal }\end{array}$ https://www.balairungpress.com/2017/12/lepasnya-aliran-kepercayaan-daribelenggu-diskriminasi/

Basit, Abdul. (2017). Strategi perlawanan kelompok penghayat kapribaden terhadap diskriminasi agama (studi kasus di dusun kalianyar desa ngunggahan kecamatan bandung kabupaten tulungagung). Skripsi. IAIN Tulungagung. 
Budiantoro, Totok. (2019). Paguyuban penghayat kapribaden. Diakses tanggal 4 Agustus 2021. http://menaramadinah.com/14289/paguyuban-penghayat-kapribaden.html

Budiarta, I Wayan. (2020). Laku urip kasampurnan jati. Badung: Nilackra.

Endraswara, Suwardi. (2015). Agama jawa: ajaran, amalan, dan asal usul kejawen. Jakarta: Narasi.

Fauziyah, Siti. (2014). Spiritualitas ajaran penghayat kapribaden. Religi: Jurnal Studi Agama-Agama, X (1), 12-26. https://doi.org/10.14421/rejusta.2014.1001-02

Fikriaono, Muhaji. (2018). Kawruh jiwa: warisan spiritual ki ageng suryomentaram. Javanica.

Jalaluddin, R. (2007). Psikologi agama: memahami perilaku keagamaan dengan mengaplikasikan prinsip-prinsip psikologi. PT Rajagrafindo Persada.

Kalama, Sudhana. (2013). Ketuhanan dalam ajaran buddha. Diakses pada tanggal 3 Agustus 2021. https://www.kompasiana.com/sudhana/ 552cac7c6ea8345a428b4581/ketuhanan-dalam-ajaran-buddha

Koentjaraningrat. (1979). Manusia dan kebudayaan di indonesia. Djambatan.

Koentjaraningrat. (1993). Ritus peralihan di indonesia. Balai Pustaka.

Kumparan. (2021). Pengertian habluminannas dan pentingnya bagi seorang muslim.

Diakses pada tanggal 5 Agustus 2021. https://kumparan.com/berita-hariini/pengertian-habluminannas-dan-pentingnya-bagi-seorang-muslim1v4bKZBzrl6/full

Nadlir, Moh. (2017). Ada 187 kelompok penghayat kepercayaan yang terdaftar di pemerintah. Diakses pada tanggal 2 Agustus 2021. https://nasional.kompas.com/read/2017/11/09/12190141/ada-187-kelompokpenghayat-kepercayaan-yang-terdaftar-di-pemerintah?page=all

Nurhalizah, Mevy Eka. (2020). Proses integrasi dan strategi komuniaksi kelompok minoritas penghayat kepribaden dalam kultur diskriminasif di desa candipari, sidoarjo. Jurnal Dinamika Penelitian, $20 \quad$ (1), $18 \quad$ - 41. https://doi.org/10.21274/dinamika.2020.20.1.18-41

Nurwardani, Paristiyanti, Hestu Yoga Saksama, Uung Sudiana, Edi Mulyono, Sanityas Jukti Prawatyani, Aan Almaidah Anwar, Evawany, Fajar Priyautama, Ary Festanto, \& Rudi Ismoyo. (2016). Pendidikan agama khonghucu. Direktorat Jenderal Pembelajaran dan Kemahasiswaan.

Paguyuban Penghayat Kapribaden. https://www.kapribaden.org/index.php 
Poerwandari, E.K. (2007). Pendekatan kualitatif dalam penelitian psikologi. LPSP3 Universitas Indonesia.

Qutubi, Sumanto Al, \& Izak Lattu (ed.). (2019). Tradisi dan kebudayaan nusantara. Semarang: Elsa Press.

Qutubi, Sumanto Al, \& Tedi Kholiludin (ed.). (2019). Agama dan kepercayaan nusantara. Elsa Press.

Raharjo, Wahyono. (1993). Buku hidup bahagia yang diakhiri dengan kasampurnaan jati. Paguyuban Penghayat Kapribaden.

Ramlan, Roni. (2018). Konsep nasionalisme dalam ajaran paguyuban penghayat kapribaden di tulungagung. Kontemplasi: Jurnal Ilmu-Ilmu Ushuluddin, 6 (2), 183 - 206. https://doi.org/10.21274/kontem.2018.6.2.183-206

Sapardi. Modul ketuhanan yang maha esa dalam perspektif agama buddha. Universitas Terbuka.

Sholeh, Mochamad. (2017). Konsep perbuatan manusia dalam pandangan aliran kepercayaan kapribaden. Skripsi. IAIN Tulungagung.

Syafi'udin, Moch. (1996). Konsepsi manusia menurut penghayat kapribaden. Skripsi. Institut Agama Islam Negeri Sunan Ampel Surabaya.

Widhana, Dieqy Hasby. (2019). Kisah penghayat kapribaden menghadapi diskriminasi negara. Diakses pada tanggal 5 Agustus 2021. https://tirto.id/kisah-penghayatkapribaden-menghadapi-diskriminasi-negara-cCrS

Zulkfli, Muhammad, Budiaman, \& Nova Scorviana. (2019). Resistensi Majelis Luhur Kepercayaan Terhadap Tuhan Yang Maha Esa Indonesia (MLKI) dalam Mempertahankan Keyakinan Yang Dianut. Jurnal Edukasi IPS, 3 (1), 1 - 8. https://doi.org/10.21009/EIPS.003.1.01 